\title{
Diet and diet combined with chronic aerobic exercise decreases body fat mass and alters plasma and adipose tissue inflammatory markers in obese women
}

N Lakhdar ${ }^{1,2^{*}}$, M Denguezli ${ }^{1,2,3}$, M Zaouali ${ }^{1,2,3,4}$, A Zbidi ${ }^{1,2,3,4,5}$, Z Tabka $^{1,2,3,4,5}$, A Bouassida $a^{1,2,3,4,5}$

From 8th International Congress of Familial Mediterranean Fever and Systemic Autoinflammatory Diseases Dresden, Germany. 30 September - 3 October 2015

The purpose of this study was to investigate the effect of 6 months aerobic exercise and diet alone or in combination on markers of inflammation (MOI) in circulation and in adipose abdominal tissue (AT) in obese women. Thirty obese subjects were randomized into a 24 weeks intervention: 1) exercise (EX), 2) diet (DI) and 3) exercise and diet (EXD). Blood samples were collected at baseline, after $12 \mathrm{wk}$ and $24 \mathrm{wk}$. AT biopsies were obtained only at baseline and after $24 \mathrm{wk}$. In the EXD and DI groups the fat loss was after $12 \mathrm{wk}-13.74 \%$ and $-7.8 \%(\mathrm{P}<0.01)$ and after $24 \mathrm{wk}-21.82 \%$ and $-17 \%$ $(\mathrm{P}<0.01)$ with no changes in the EX group. After 12 and 24 wk, $\mathrm{VO}_{2}$ max was increased by $21.81-39.54 \%$ $(\mathrm{P}<0.05)$ in the EXD group and $18.09-40.95 \%$ in the EX group with no changes in the DI group. In the EXD and DI groups, circulating levels of TNF-a and IL- 6 were decreased after $24 \mathrm{wk}$ for both groups $(\mathrm{P}<0.01)$. No changes in the EX group. HOMA-R decreased $(\mathrm{P}<0.05)$ only after 24 wk in the EXD group. In AT biopsies, subjects in the EXD and DI groups exhibited a significant decrease in $\mathrm{MO}(\mathrm{P}<0.01$ for all). No changes in AT biopsies were found in the EX group. In conclusion, chronic aerobic exercise was found to have no effects on circulating and AT MOI despite an increased $\mathrm{VO}_{2}$ max. Rather important body composition modifications were found to have beneficial effects on circulating and AT MOI in these obese women.

\section{Authors' details}

${ }^{1}$ Research Unit of Sportive Performance and Physical Rehabilitation, High Institute of Sports and Physical Education, Physiology, El Kef, Tunisia. ${ }^{2}$ High Institute of Sports and Physical Education, Research Unit of Sportive Performance and Physical Rehabilitation, El Kef, University of Jendouba, Tunisia. ${ }^{3}$ Laboratory of Cardio-Circulatory, Respiratory, Metabolic and Hormonal Adaptations to Muscular Exercise, Faculty of Medicine Ibn El Jazzar, Physiology, Sousse, Tunisia. ${ }^{4}$ Laboratory of Cardio-Circulatory, Respiratory, Metabolic and Hormonal Adaptations to Muscular Exercise, Physiology, Sousse, Tunisia. ${ }^{5}$ Research Unit of Sportive Performance and Physical Rehabilitation, Physiology, El Kef, University of Jendouba, Tunisia, Tunisia.

Published: 28 September 2015

\section{doi:10.1186/1546-0096-13-S1-P194}

Cite this article as: Lakhdar et al.: Diet and diet combined with chronic aerobic exercise decreases body fat mass and alters plasma and adipose tissue inflammatory markers in obese women. Pediatric Rheumatology 2015 13(Suppl 1):P194.

\section{Submit your next manuscript to BioMed Central} and take full advantage of:

- Convenient online submission

- Thorough peer review

- No space constraints or color figure charges

- Immediate publication on acceptance

- Inclusion in PubMed, CAS, Scopus and Google Scholar

- Research which is freely available for redistribution
Research Unit of Sportive Performance and Physical Rehabilitation, High Institute of Sports and Physical Education, Physiology, El Kef, Tunisia Full list of author information is available at the end of the article 